\title{
UJI BAKTERIOLOGIS COLIFORM DAN ESCHERICHIA COLI PADA AIR TANAH BEBAS
}

\author{
Fadhila Afifah \\ Jurusan Teknik Lingkungan, Fakultas Arsitektur Lanskap dan Teknologi Lingkungan, \\ Universitas Trisakti, Jakarta, Indonesia
}

Email korespondensi: fadhila08213018@std.trisakti.ac.id

\begin{abstract}
ABSTRAK
Air tanah (groundwater) merupakan salah satu sumber daya alam yang diperlukan untuk hidup manusia. Peningkatan populasi penduduk di suatu wilayah akan mempengaruhi tingkat kepadatan penduduk di wilayah tersebut. Padatnya pemukiman penduduk menyebabkan kualitas dan kuantitas dari air bersih berkurang. Berkurangnya kualitas air ini ditinjau dari jarak sumur air tanah dengan tangki septik, baik berdasarkan jarak sumur air tanah dengan tangki septik di dalam rumah sendiri maupun jarak sumur air tanah dengan tangki septik tetangga. Air merupakan medium pembawa mikroorganisme patogenik yang berbahaya bagi kesehatan. Untuk mencegah penyebaran penyakit melalui air perlu dilakukan kontrol terhadap polusi air terutama dengan pemeriksaan mikroorganisme di dalam air. Seiring dengan peningkatan jumlah penduduk di daerah tersebut, maka akan semakin meningkat pula kebutuhan air bersih. Apabila sanitasi masyarakat kurang baik maka akan terjadi pencemaran lingkungan dimana akan mengakibatkan meningkatnya jumlah bakteri Escherichia Coli (E. Coli).
\end{abstract}

Kata Kunci: air tanah, koliform, escherichia coli

\section{PENDAHULUAN}

Air tanah secara umum oleh masyarakat digunakan untuk kebutuhan minum dan memasak karena air tanah dianggap memiliki kualitas yang lebih baik dibandingkan dengan air sungai. Oleh karena itu, sumber daya air tanah ini harus dilindungi agar dapat tetap dimanfaatkan oleh manusia serta makhluk hidup yang lain. Pemanfaatan air untuk berbagai kepentingan harus dilakukan dengan cara yang bijaksana, dengan memperhitungkan kepentingan generasi sekarang dan generasi mendatang. Peningkatan populasi penduduk di suatu wilayah akan mempengaruhi tingkat kepadatan penduduk di wilayah tersebut. Meningkatnya populasi penduduk mengakibatkan kebutuhan atas ketersediaan air meningkat, namun disisi lain dampak dari peningkatan kepadatan penduduk yaitu berkurangnya ketersediaan lahan untuk resapan air, karena lahan tersebut tertutup oleh jalanan maupun bangunan yang dibangun diatasnya. Padatnya pemukiman penduduk menyebabkan kualitas dan kuantitas dari air bersih berkurang. Berkurangnya kualitas air ini ditinjau dari jarak sumur air tanah dengan tangki septik, baik berdasarkan jarak sumur air tanah dengan tangki septik di dalam rumah sendiri maupun jarak sumur air tanah dengan tangki septik tetangga.

Dari aspek kuantitas dan kualitas, air tanah lebih baik dari pada air permukaan. Berdasarkan data BPLHD tahun 2015, 70 dari 189 kondisi sumur di DKI Jakarta tercemar bakteri E. coli. Pengunaan air yang mengandung bakteri E. coli untuk dikonsumsi dapat menyebabkan penyakit diare, kram perut, kelelahan dan demam. Berdasarkan Baku Mutu Air Minum Permenkes No. 492 Tahun 2010 jumlah bakteri E. coli di air minum pada air sumur 
adalah nol/100 ml. Atas dasar kondisi di atas maka dilakukan penelitian mengenai kualitas air tanah secara bakteriologis yang dikaitkan dengan keadaan sanitasi lingkungan sekitar serta mengukur pola distribusi bakteri koliform dan E. Coli.

\section{TINJAUAN PUSTAKA}

\section{Air Tanah}

Berdasarkan Peraturan Menteri Energi Dan Sumber Daya Mineral Republik Indonesia No. 15 tahun 2012, Air tanah adalah air yang terdapat dalam lapisan tanah atau batuan dibawah permukaan tanah. Air tanah merupakan bagian air di alam yang terdapat di bawah permukaan tanah. Pembentukan air tanah mengikuti siklus peredaran air di bumi yang disebut daur hidrologi, yaitu proses alamiah yang berlangsung pada air di alam yang mengalami perpindahan tempat secara berurutan dan terus menerus (Kodoatie, 2012).

\section{Bakteri Koliform}

Total bakteri koliform biasa terjadi di lingkungan (tanah atau vegetasi) dan umumnya tidak berbahaya. Jika laboratorium hanya mendeteksi bakteri koliform total dalam air minum, sumbernya kemungkinan kontaminasi lingkungan dan kotoran tidak mungkin terjadi. Namun, jika pencemaran lingkungan bisa masuk sistem, patogen bisa masuk juga. Penting untuk menemukan dan mengatasi sumber kontaminasi. Bakteri Coliform fecal adalah sub kelompok bakteri coliform total. Mereka ada di usus dan kotoran manusia dan hewan (WA Depth Health, 2016).

\section{Bakteri Koliform}

Bakteri E. Coli merupakan kelompok bakteri Coliform, semakin tinggi tingkat kontaminasi bakteri Coliform semakin tinggi pula resiko kehadiran bakteri pathogen lainnya yang biasa hidup dalam kotoran manusia yang dapat menyebabkan diare. Tingginya tingkat penyakit diare berkaitan dengan bakteri E. Coli yang terdapat di Indonesia, khususnya dikota-kota kecil. Minimnya pengetahuan masyarakat awam tentang bahaya akan bakteri E. Coli mengakibatkan kurangnya kesadaran untuk mendeteksi dan mengambil langkah-langkah pencegahan terhadap bakteri tersebut (Santoso, 2008). E. Coli merupakan bakteri komensal yang dapat bersifat patogen, bertindak sebagai penyebab utama morbiditas dan mortalitas diseluruh dunia (Tenailon dkk., 2010).

\section{Dampak Pencemaran Air Tanah}

Menurut Sudarmadji (2017), pencemaran air tanah membawa dampak buruk bagi kehidupan manusia. Diantara dampak buruk tersebut yaitu :

a) Berkurangnya persediaan air bersih karena air tanah sebagai sumber air bersih sudah tercemar. Jika ketersediaan air tidak mencukupi kebutuhan sehari- hari seperti minum, mandi, mencuci dan kakus, maka akan terjadi kelangkaan air bersih yang berdampak pada berkurangnya produktivitas manusia.

b) Naiknya populasi bakteri- bakteri berbahaya. Bakteri yang bersifat phatogen akan berkembangbiak dengan cepat di dalam air yang tercemar. Tingginya populasi bakteri phatogen juga akan mengurangi tingkat oksigen di dalam air.

c) Turunnya tingkat kesehatan. Mengkonsumsi dan menggunakan air tanah yang tercemar dapat menimbulkan berbagai macam penyakit seperti diare, muntaber, disentri, gatal- gatal dan penyakit- penyakit lainnya. Jika air tanah yang dikonsumsi ternyata tercemar oleh limbah yang mengandung logam maka berpotensi menimbulkan kanker dan penyakit yang menyerang darah. 


\section{Most Probable Number (MPN)}

MPN adalah metode enumerasi mikroorganisme yang menggunakan data dari hasil pertumbuhan mikroorganisme pada medium cair spesifik dalam seri tabung yang ditanam dari sampel padat atau cair sehingga dihasilkan kisaran jumlah mikroorganisme dalam jumlah perkiraan terdekat (Harti, 2015).

Berdasarkan Baku Mutu Permenkes Nomor 492 Tahun 2010 tentang Persyaratan Kualitas Air Minum, Untuk parameter bakteri koliform maupun E. Coli keberadaannya tidak diperbolehkan ada di dalam air minum, maka dilakukan penelitian mengenai kualitas air tanah secara bakteriologis yang dikaitkan dengan keadaan sanitasi lingkungan sekitar serta mengukur pola distribusi bakteri koliform dan E. Coli.

Tabel 1. Penelitian Terkait Uji Bakteriologi Pada Air Tanah

\begin{tabular}{lrc}
\hline \multicolumn{2}{c}{ Judul Paper, Tahun } & Penulis \\
\hline Kualitas Air Tanah Di & Budi Rahayu \\
Kecamatan & Tebet & Kosasih, \\
Jakarta Selatan Ditinjau & Samsuhadi, \\
Dari Pola Sebaran & Novita Indri \\
Escherichia Coli, 2009 & Astuty
\end{tabular}

Kualitas Air Tanah Di Sepanjang Kali Gajah Wong Ditinjau Dari Pola Sebaran Escherichia Coli (Studi Kasus

Kecamatan Umbulharjo), 2013

Kualitas Air Sumur Gali Ditinjau Dari Kondisi Lingkungan Fisik Dan Perilaku Masyarakat Di Wilayah Puskesmas I Denpasar Selatan, 2008
Ekrar Winata, Eddy Hartantyo Hasil Penelitian Hasil penelitian menunjukkan bahwa jumlah bakteri E. coli pada air tanah di Kecamatan Tebet berkisar antara $3 \mathrm{MPN} / 100$ ml sampai $160 \mathrm{MPN} / 100 \mathrm{ml}$. Dari hasil uji korelasi diketahui bahwa jumlah bakteri E. coli pada air tanah dipengaruhi oleh kedalaman sumur dan jarak tangki septik terhadap sumur air tanah. Semakin rendah kedalaman sumur air tanah dan semakin dekat jarak tangki septik terhadap sumur air tanah maka semakin buruk kualitas air tanahnya dan jumlah bakteri E. coli yang terkandung di dalam air tanah pun semakin banyak.

Kandungan golongan bakteri coli pada air tanah di sepanjang Kali Gajah Wong sangat tinggi, sebanyak $46 \%$ penyebaran E.coli berada diatas ambang batas yaitu $2400 \mathrm{mg} / \mathrm{l}$ pada titik 1, $6,22,24,25,26,27,28,29,31,32,33,34,35,36,38,40,44$, $45,46,48,49$.

Kandungan total coliform yang melebihi baku mutu air kelas I Peraturan Gubernur Bali No.8 tahun 2007 adalah 2 (dua) sampel dengan nilai masing-masing $1100 \mathrm{MPN} / 100 \mathrm{ml}$ air pada bulan februari, dan hasil analisis sampel air bulan April 2008 terdapat 6 (enam) sampel air sumur melebihi baku mutu yang diperbolehkan yaitu $500 \mathrm{MPN} / 100 \mathrm{ml}$ air dan berdasarkan Permenkes R.I No.907 tahun 2002 semua air sampel tidak memenuhi baku mutu air minum yaitu 0 (nol) MPN/100 ml. Terjadinya perubahan coliform total pada air sumur dalam dua periode pengambilan sampel air dikarenakan disamping faktor lingkungan fisik sumur seperti adanya genangan air disekitar sumur, adanya sumber pencemar lain seperti sampah dan limbah rumah tangga yang meresap ke dalam air tanah,

\begin{tabular}{lc}
\hline Assessment of Selected & Chin Yik Lin, \\
Chemical and Microbial & Mohd. Harun \\
Parameters in & Abdullah, Baba \\
Groundwater of Pulau & Musta, Ahmad \\
Tiga, Sabah, Malaysia, & Zaharin Aris \& \\
2009 & Sarva Mangala \\
& Praveena
\end{tabular}
Di Pulau Tiga, meskipun sumur tertutup dikelola dengan baik, namun masih menunjukkan terindikasinya adanya sejumlah bakteri. Hal ini mungkin terkait dengan terjadinya kebocoran di septic tank terdekat yang merupakan sumber tertinggi untuk kontaminasi tinja. Secara komparatif, hasil coliform yang lebih rendah ditemukan di PT 1 (total coliform - 27 CFU / 100 ml, fecal coliform - 5 CFU / $100 \mathrm{~mL}$ selama Agustus 2007, total coliform - $12 \mathrm{CFU} / 100 \mathrm{~mL}$, fecal coliform - 0 CFU / $100 \mathrm{ml}$ selama November 2007) dan PT 2 (total coliform - 43 CFU / 100 mL, fecal coliform - 9 CFU / 100 mL selama Agustus 2007; total coliform - $2 \mathrm{CFU} \mathrm{/} 100 \mathrm{~mL}$; fecal coliform - $0 \mathrm{CFU} / 100$ $\mathrm{mL}$ selama November 2007). Analisis bakteriologis menunjukkan bahwa kualitas air tanah rendah, dengan jumlah 
coliform fecal melebihi WHO batas yang diperbolehkan untuk air minum. Melalui penelitian ini, faktor manusia adalah untuk disalahkan untuk coliform kontaminasi kotoran di mana air tanah tercemar mungkin berasal dari fasilitas sanitasi terletak terlalu dekat dengan sumur. Terjadinya total dan fecal coliform bakteri dalam jumlah menyarankan penanganan sanitasi yang buruk dan memperingatkan adanya potensi organisme penyebab penyakit

\begin{tabular}{lcc}
\hline Pencemaran Air Tanah & Kadek Diana \\
Akibat & Pembuangan & Harmayani Dan I \\
Limbah & Domestik Di & G. M.
\end{tabular}

Lingkungan Kumuh Studi Kasus Banjar Ubung Sari, Kelurahan Ubung, 2007
Hasil yang didapatkan pada titik sampel 1 yaitu 28/100 ml untuk jumlah E. Coli dan 1100/100 ml untuk bakteri koliform. titik sampel 2 yaitu 0/100 ml untuk jumlah E. Coli dan 0/100 ml untuk bakteri koliform. titik sampel 3 yaitu $0 / 100 \mathrm{ml}$ untuk jumlah E. Coli dan 240/100 ml untuk bakteri koliform. titik sampel 4 yaitu 3/100 ml untuk jumlah E. Coli dan 1100/100 ml untuk bakteri koliform. titik sampel 5 yaitu 3/100 ml untuk jumlah E. Coli dan 150/100 ml untuk bakteri koliform.

\begin{tabular}{lr}
\hline Uji Mpn & Bakteri \\
Escherichia & Coli Pada \\
Air Sumur & Berdasarkan \\
Perbedaan & Konstruksi \\
Sumur Di & Wilayah \\
Nagrak Kabupaten & \\
Ciamis, 2016 &
\end{tabular}

\begin{tabular}{|c|c|}
\hline Studi Kualitas Air Tanah & Pramudita Dewi \\
\hline Terhadap & P, Emma Yuliani, \\
\hline Kandungan & Riyanto \\
\hline Escherichia & Haribowo. \\
\hline Kelurahan & \\
\hline Cisarua Dan Kelurahan & \\
\hline Subangjaya Kecamatan & \\
\hline $\begin{array}{l}\text { Cikole Kota Sukabumi, } \\
2015\end{array}$ & \\
\hline
\end{tabular}

\begin{tabular}{lrc}
\hline Pencemaran & Limbah & Anna Fadliah \\
Domestik Dan Pertanian & Rusydi, Wilda \\
Terhadap $\quad$ Airtanah & Naily, Hilda \\
Bebas Di Kabupaten & Lestiana \\
Bandung 2015 &
\end{tabular}

Nilai rata-rata MPN air sumur dengan konstruksi beton pada titik sampel 1,2,3 adalah 23/100 mL, 39/100 mL, 23/100 mL dan nilai rata-rata MPN air sumur dengan konstruksi non beton sampel 1 dan 2 adalah 210/100 mL dan 1100/100 mL. Hal ini terjadi karena pada konstruksi sumur non beton mempunyai konstruksi sumur seadanya tidak menggunakan batu bata dan tidak diplester sehingga air dengan mudah dapat membawa kotoran masuk ke dalam sumur.

Berdasarkan hasil penelitian dan pembahasan, pada Kelurahan Subangjaya rata-rata nilai kandungan yang di teliti sebesar 32400/100 ml dengan batas yang dikeluarkan oleh menteri kesehatan no 416/MEN.KES/ PER/IX/1990 ialah $\leq 50$ $\mathrm{MPN} / 100 \mathrm{ml}$ untuk bakteorologis.
Total coliform dan fecal coliform ditemukan pada 7 lokasi, yaitu di Margahayu, Pangalengan, Margaasih dan Rancaekek. Pencemar solid bersumber dari limbah domestik yang didukung dengan kondisi sumur yang terbuka, dan pencemaran nitrat kemungkinan disebabkan oleh kegiatan pertanian (perkebunan) yang sudah beroperasi lebih dari seratus tahun di lingkungan tersebut. Kontaminasi ammonium berasal dari limbah domestik (urin dan feses) yang ada di sekitar sumur, sementara kontaminasi coliform berasal dari tinja manusia dan hewan berdarah panas yang terdapat dalam tangki septik dan saluran air terbuka yang digunakan sebagai toilet.

\begin{tabular}{lrr}
\hline Tingkat & Kualitas & Lintje Boekoesoe \\
Bakteriologis & Air Bersih & \\
Di Desa & Sosial & \\
Kecamatan & Paguyaman \\
Kabupaten & Boalemo \\
2010 &
\end{tabular}

Pemeriksaan laboratorium dilakukan dengan menggunakan metode MPN seri 3 tabung kemudian nilai pada tabel MPN dikalikan dengan 1 /faktor pengenceran ditengah. Sedangkan uji penguat coliform digunakan untuk melihat positif atau negatif adanya bakteri Escherichia coli. Setelah dilakukan uji penduga didapatkan hasil yang paling banyak mengandung bakteri E. coli yaitu air sumur non beton dengan rata-rata 2,4 x 103 100/ ml, sedangkan pada uji penguat terdapat 8 titik sampel positif ditemukan adanya E. coli. Pada air sumur Beton dan Suntik hanya terdapat 2 titik sampel yang terindikasi positif terdapat $E$. coli dengan rata-rata air sumur beton $1,3 \times 101 / 100 \mathrm{ml}$ dan air sumur suntik $0,95 \times 101 / 100 \mathrm{ml}$. 


\begin{tabular}{|c|c|c|}
\hline Judul Paper, Tahun & Penulis & Hasil Penelitian \\
\hline Uji Kualitas Air Sumur & Riri Novita & Dari hasil penelitian didapatkan nilai MPN 12 air sumur gali di \\
\hline Dengan Menggunakan & Sunarti & RT.V Kelurahan Padang Jati tidak memenuhi persyaratan sesuai \\
\hline Metode MPN (Most & & Keputusan Menteri Kesehatan \\
\hline $\begin{array}{l}\text { Probable } \\
2015\end{array}$ & & $\begin{array}{l}\text { 907/MenKes/SK/VII/202 tentang persyaratan kualitas air } \\
\text { minum khususnya keberadaan Coliform dalam air minum. } \\
\text { Sehingga air minum yang berasal dari } 12 \text { sumur gali tersebut } \\
\text { tidak layak untuk dikonsumsi oleh masyarakat karena } \\
\text { mengandung Coliform sehingga mempunyai efek yang tidak } \\
\text { baik untuk kesehatan. }\end{array}$ \\
\hline
\end{tabular}

Dari hasil analisa tabel 1. Berdasarkan Baku Mutu Permenkes Nomor 492 Tahun 2010 tentang Persyaratan Kualitas Air Minum, Untuk parameter bakteri koliform maupun E. Coli keberadaannya tidak diperbolehkan ada di dalam air minum, tetapi didapatkan bahwa sebagian besar air tanah mengandung bakteri coliform, namun tidak semua air tanah mengandung bakteri $E$. Coli ini dikarenakan oleh kondisi lingkungan dan faktor-faktor lainnya salah satunya adalah jarak antara sumber air terhadap tangki septik.

\section{PENUTUP}

Kontaminasi coliform berasal dari tinja manusia dan hewan berdarah panas yang terdapat dalam tangki septik. Kebocoran tangki septik merupakan penyebab terkontaminasinya air tanah dengan coliform dan E. Coli. Sebagian besar dari hasil penelitian tersebut, air tanah mengandung bakteri coliform, tetapi tidak semua air tanah mengandung bakteri $E$. Coli ini dikarenakan oleh kondisi lingkungan dan faktor-faktor lainnya seperti jarak antara sumber air terhadap tangki septik, cuaca, intensitas hujan dan aktivitas manusia yang berada di sekitar sumber air tanah. Berdasarkan baku mutu air minum keberadaan bakteri coliform dan E. Coli tidak diperbolehkan, karena jika dikonsumsi oleh manusia akan menimbulkan penurunan tingkat kesehatan yang dapat menimbulkan berbagai macam penyakit seperti diare, muntaber, disentri, gatal- gatal dan penyakit- penyakit lainnya. Jika ingin tetap menggunakan air tanah untuk kebutuhan rumah tangga sebaiknya diolah terlebih dahulu sebelum dikonsumsi.

\section{DAFTAR PUSTAKA}

Republik Indonesia. 2010. Peraturan Menteri Kesehatan Republik Indonesia No. 492/MENKES/PER/IV/2010, tentang Persyaratan Kualitas Air Minum. Jakarta

Departement of Health State of Western Australia. 2016. Annual Report 2015-2016. Departement of Health State of Western Australia, Perth: Health Network Branch

Kodoatie, Robert J. 2012. Tata Ruang Air Tanah. Penerbit Andi, Yogyakarta

Tenailon O, Skurnik D, Picard B, Denamur E. 2010. The Population Genetics of Commensal Escherichia coli. Us National Library of Medicine, National Institutes of Health.

Sudarmadji, Hadi, P., dan Widyastuti, M. 2016. Pengelolaan Sumberdaya Air Terpadu, Gadjah Mada University Press. Yogyakarta.

Harti, Sri. 2015. Mikrobiologi Kesehatan. Yogyakarta: CV. ANDI OFFSET

Irwansyah, Edy. 2013. Sistem Informasi Geografis: Prinsip Dasar dan Pengembangan Aplikasi. Yogyakarta : Digibooks

Kosasih, Samsuhadi, astuty. 2009 Kualitas Air Tanah Di Kecamatan Tebet Jakarta Selatan Ditinjau Dari Pola Sebaran Escherichia Coli 
Winata \& Hartantyo, 2013. Kualitas Air Tanah Di Sepanjang Kali Gajah Wong Ditinjau Dari Pola Sebaran Escherichia Coli (Studi Kasus Kecamatan Umbulharjo),

Marwati, Mardani \& Sundra. 2008. Kualitas Air Sumur Gali Ditinjau Dari Kondisi Lingkungan Fisik Dan Perilaku Masyarakat Di Wilayah Puskesmas I Denpasar Selatan

Lin, Abdullah, Musta, Aris \& Praveena. 2009. Assessment of Selected Chemical and Microbial Parameters in Groundwater of Pulau Tiga, Sabah, Malaysia

Harmayani \& Konsukartha. 2007. Pencemaran Air Tanah Akibat Pembuangan Limbah Domestik Di Lingkungan Kumuh Studi Kasus Banjar Ubung Sari, Kelurahan Ubung

Yuliana. 2016. Uji Mpn Bakteri Escherichia Coli Pada Air Sumur Berdasarkan Perbedaan Konstruksi Sumur Di Wilayah Nagrak Kabupaten Ciamis

Dewi, Yuliani \& Hariwibowo. 2015. Studi Kualitas Air Tanah Dangkal Terhadap Kandungan Bakteri Escherichia Coli di Wilayah Kelurahan Cisarua Dan Kelurahan Subangjaya Kecamatan Cikole Kota Sukabumi

Rusdyi, Naily \& Lestiana. 2015. Pencemaran Limbah Domestik Dan Pertanian Terhadap Airtanah Bebas Di Kabupaten Bandung

Boekoesoe. 2010. Tingkat Kualitas Bakteriologis Air Bersih Di Desa Sosial Kecamatan Paguyaman Kabupaten Boalemo

Sunarti. 2015. Uji Kualitas Air Sumur Dengan Menggunakan Metode MPN (Most Probable Numbers) 